\title{
APPLICATION OF DISTRIBUTED HYDROLOGICAL MODEL TO ANALYZE BRIDGE-COLLAPSE SCENARIOS IN THE ASUWA RIVER 2004 FLOOD
}

\author{
NMNS Bandara NAWARATHNA ${ }^{1}$, Kazuo ISHINO ${ }^{2}$ Yasuto TACHIKAWA $^{3}$ and \\ Nobuyuki TAMAI ${ }^{4}$ \\ ${ }^{1}$ Member of JSCE, Dr. of Eng., Taisei Technology Center (344-1, Nase-cho, Totsuka-ku, Yokohama, Japan) \\ ${ }^{2}$ Member of JSCE, Dr. of Eng., Taisei Technology Center (344-1, Nase-cho, Totsuka-ku, Yokohama, Japan) \\ ${ }^{3}$ Member of JSCE, Dr. Eng., DPRI, Kyoto University, (Gokasho, Uji, 611-0011, Japan) \\ ${ }^{4}$ Fellow of JSCE, Dr. of Eng., Kanzawa University (Kakuma, Kanazawa 920-1192, Japan)
}

In July 2004, torrential rain induced by baiu-front caused devastating floods in the Asuwa River basin damaging five railway bridges between Fukui and Miyama stations on the JR Etsumi Hoku line. The Asuwa River basin has only one river gauging and two AMeDAS ground rainfall measuring stations. Those limited data are not sufficient to forecast the heavy floods caused by unprecedented downpours. A physically based distributed TOPMODEL with Muskingum-Cunge flow routing method and radar derived rainfall intensities are used to simulate hydrological processes of the basin. Results show good agreements with observed discharges at Tenjinbashi gauging river station. Simulated distributed discharge values are used to compute the bending stresses of the collapsed railway bridge piers and compared with respective bearing capacities. The main objective of this paper is to introduce the state of art of distributed hydrological modeling with radar derived rainfall inputs to identify the river structures along the river channel that are vulnerable to floods.

Key Words: Fukui heavy rainfall in July 2004, distributed hydrological model, bridge collapse, radar rainfall

\section{INTRODUCTION}

In 2004, heavy rainfall related natural disasters caused more than 230 casualties in Japan. Those heavy rainfalls were induced by 10 strong typhoons and intensified baiu-front. Among these the heaviest torrential rainfall was caused by the active seasonal rain front and ravaged Niigata, Fukushima and Fukui prefectures.

On July $18^{\text {th }}$, torrential rains in Fukui prefecture caused devastating floods and mudslides in the Asuwa River basin. The observed peak discharge at the Tenjinbashi $\left(2320 \mathrm{~m}^{3} / \mathrm{s}\right)$ was almost two times larger than the previously recorded peak discharge ${ }^{1)}$. Six hour and daily accumulated rainfall on $18^{\text {th }}$ at Kidouchi was $314 \mathrm{~mm}$ and $338 \mathrm{~mm}$ respectively. These unprecedented river discharges resulted in bursts of riverbank and spilling the levees, partly inundating Fukui city. Five people were drowned or went missing. More than 14,000 houses were flooded. Five bridges between Fukui and Miyama stations on the JR Etsumi Hoku Line were washed away. Consequently train services were suspended

Ishino et al.(2005) has studied bridge collapsing mechanism using a constant river discharge (2400 $\mathrm{m}^{3} / \mathrm{s}$ ) along the Asuwa River ${ }^{2}$. In this paper we apply a physically based distributed TOPMODEL coupled with Muskingum-Cunge flow routing method and radar derived rainfall intensities to simulate hydrological processes of the Asuwa river basin to identify river structures that are vulnerable to floods. It is found that the simulated peak discharge values of sections of collapsed railway bridges varies from $2323 \mathrm{~m}^{3} / \mathrm{s}$ to $2651 \mathrm{~m}^{3} / \mathrm{s}$. In addition, we discuss the possibility of extending this approach to analyze the risk involved with non-collapsed bridges. 


\section{ASUWA RIVER BASIN STORM CHARACTERISTICS}

During the heavy rainfall observed over Fukui area on 18 July 2004, baiu-front extending from Japan Sea to Fukui prefecture became active forming thick nimbus clouds over the region. Localized, band-shaped torrential rainstorm brought $87 \mathrm{~mm}$ of maximum hourly rainfall and $338 \mathrm{~mm}$ of daily rainfall to the area centering the Asuwa River basin (Fig. 1). This heavy rainfall was a result of an intensification of convective instability over the Baiu frontal zone, induced by the inflows of low-level humid air and middle-level dry air. The middle-level air was considerably warm, not colder than the surrounding air resulting heavy rainfall ${ }^{3)}$.

In this flood there was a 3 to 4 hour time lag between basin peak rainfall and peak observed discharge at Tenjinbashi (Fig. 2). This lead time was sufficient to advice nearly 40,000 households to evacuate to safer places in advance. However, the lead time may not be sufficient to evacuate residents from the smaller watersheds without proper river management practices. Considering these facts, it is important to develop an advanced and proper water related disaster management practices to small-scale watersheds.

\section{COMPARISON OF BASIN GROUND MEASURED RAINFALL WITH RADAR DERIVED RAINFALL}

Radar AMeDAS Precipitation (RAP) program which was developed by Japan Meteorological Agency was used to extract rainfall intensities from the AMeDAS digital radar rainfall data sheets. Excess rain water from $354 \mathrm{~km}^{2}$ catchment drains to the Tenjinbashi gauging station along the Asuwa River and its tributaries. There are 72 radar grids that falls fully or partly inside the drainage basin. Rainfall at 9:00 shows uniform distribution throughout the basin. Maximum rainfall was recorded at 10:00.

Two interpolating techniques namely; nearest neighborhood (nnm), weighed distance average (wdm) and mean of the recorded rainfall were used to estimate basin rainfall distribution from ground measured values. Hourly rainfall records at Miyama, Ono, Itagaki, Simbo, Kidouchi, Aiki, Kanemitani and Kumogawa dam stations were utilized to estimate the spatial distributions and compared with estimates from radar derived rainfall. Both nearest neighborhood and weighted distance average methods give similar values with subtle differences.

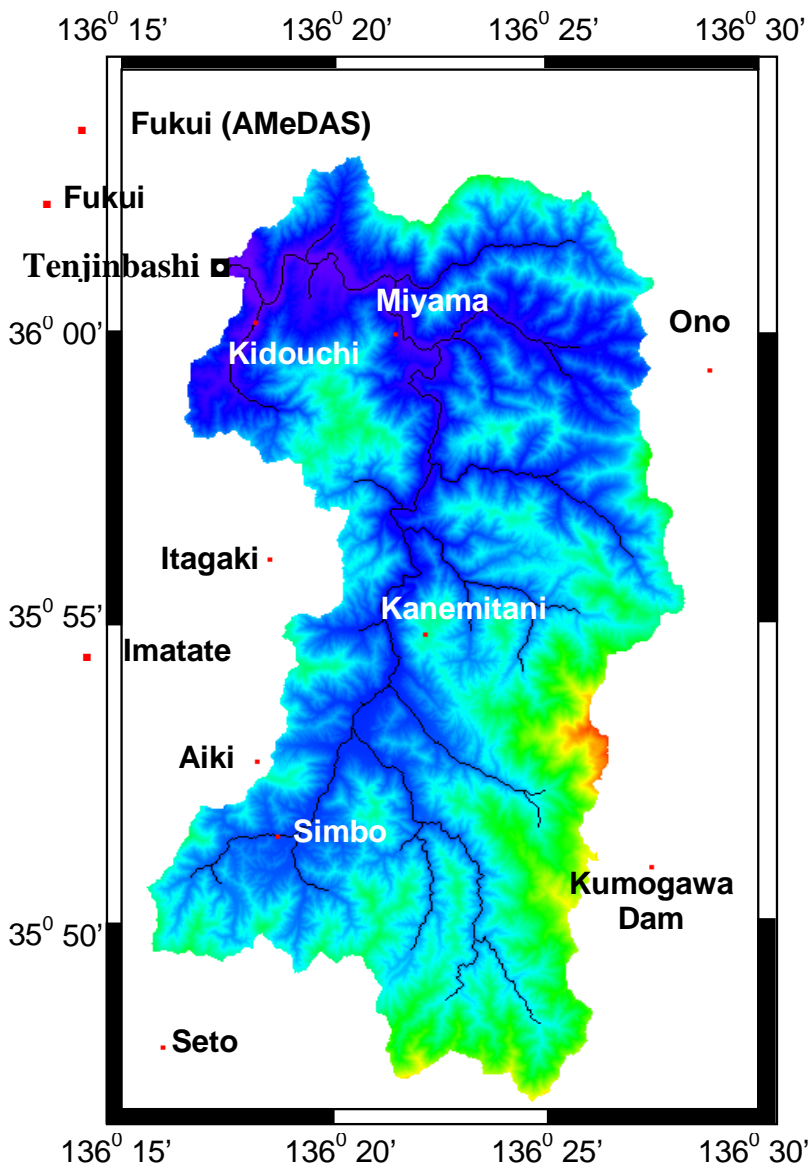

Fig.1 Ground rainfall measuring stations of the study area

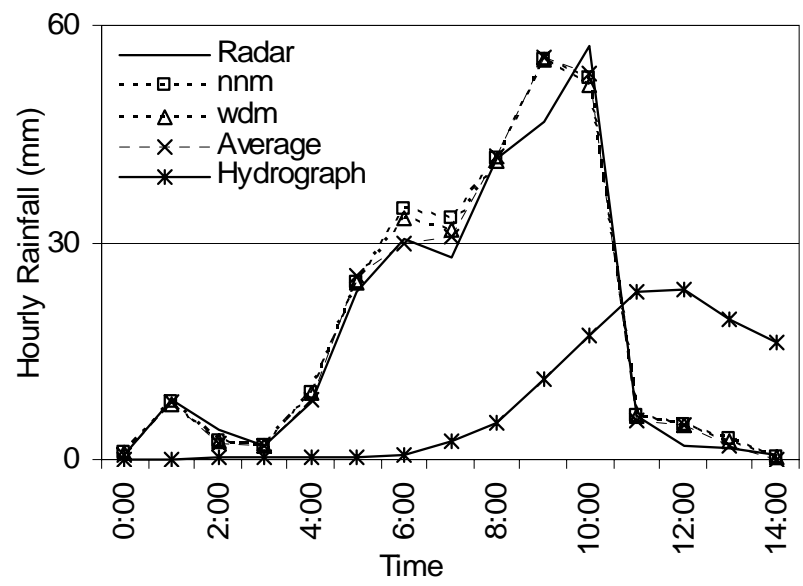

Fig.2 Spatially averaged Asuwa River basin rainfall estimates by different interpolation methods

Fig. 2 shows the spatially averaged rainfall of the basin estimated by four different methods. Radar derived estimated rainfall shows the highest deviation from other three methods at 9:00. If the routing effect and the rainfall losses are not taken into account the graph would be the flood hydrograph. But there are losses as well as time taken to route the locally generated runoff values to down stream. The amount of peak discharge reduction and lag time between peak in rain and 
discharge depend on physical characteristics of basin and the spatial and temporal distribution of rainfall. To capture those differences, we applied TOPMODEL and Muskingum-Cunge flow routing method.

It was found that spatially averaged radar derived 14 hours cumulative rainfall is about $259.9 \mathrm{~mm}$, which is about $93 \%$ of the basin averaged cumulative recorded rainfall, estimated using nearest neighborhood interpolating method (278.8 $\mathrm{mm}$ ). However differences in spatial and temporal rainfall distributions estimated by different techniques greatly influence the simulated discharges time series. A distributed hydrological model could be the best tool to capture the input effect of different rainfall distribution estimation techniques on simulated discharges.

\section{HYDROLOGICAL SIMULATION}

Modeling of hydrological processes is not an easy task even in the physically based distributed approach due to its complex governing processes and loss of information in downscaling. TOPMODEL is a small-catchment scale rainfall runoff model based on spatially distributed soil topographic index ${ }^{4}$. The BTOPMC ${ }^{5}$ model developed in Yamanashi Univeristy, Japan adopted a block wise concept to the TOPMODEL together with Muskingum-Cunge flow routing method $^{6)}$. The model was extended introducing distributed parameters and applied it to a part of the Mekong river basin ${ }^{7)}$.

\section{(1) Model structure}

In this paper, we used sub-basin TOPMODEL with Muskingum-Cunge flow routing method to simulate the hydrological processes of the Asuwa River basin for the 2004 July flood event.

The Watershed is divided into 45 imaginary sub-basins and local saturation deficit which controls the depth to the local saturation zone is calculated with respect to the sub-basin average saturation deficit value. The local saturation deficit is determined from local soil-topographic index relative to its sub-basin average value (Eq. 2). Both overland flow and base flow depend on local saturation deficit. Thus, the soil-topographic index which depends on topography and soil type is the critical controlling factor in runoff generation.

Over a sub-basin, an average saturation deficit $S(t+1)$ is determined from Eq. (1).

$$
S(t+1)=S(t)-Q_{v}(t)+Q_{b}(t)
$$

where, $S(t)$ is the sub-basin average saturation deficit at the start of time step, $Q_{v}(t)$ and $Q_{b}(t)$ are
Table 1 Land Use distribution of the Asuwa River basin

\begin{tabular}{|l|c|c|}
\hline Land Use & Area (km2) & $\mathbf{~ \% ~}$ \\
\hline Paddy Field & 17.9 & 5.1 \\
\hline Agricultural Lands & 1.1 & 0.3 \\
\hline Forest & 321.6 & 90.8 \\
\hline Waste Land & 3.9 & 1.1 \\
\hline Building Sites & 5.1 & 1.4 \\
\hline Roads & 0.4 & 0.1 \\
\hline Bare Lands & 1.5 & 0.4 \\
\hline Water Bodies & 2.7 & 0.8 \\
\hline
\end{tabular}

input to saturation zone storage from infiltration zone and groundwater discharge at the sub-basin outlet during the simulating time step.

The local saturation deficit $S(i, t)$ at grid cell $i$ is estimated with respect to the sub-basin average saturation deficit $S(t)$, and the magnitude of local soil topographical index relative to its sub-basin average value $\gamma$. In the TOPMODEL both $\gamma$ and $S(t)$ are calculated for the whole basin ${ }^{4)}$.

$$
S(i, t)=S(t)+\left(\gamma-m \ln \left(a / T_{0} \tan \beta\right)\right)
$$

where, $m$ is the decay factor that controls the rate of change of conductivity with depth in the soil profile. The value $\gamma$ can be given as follows:

$$
\gamma=\frac{1}{A} \sum_{i} m_{i} \ln \frac{a_{i}}{T_{0, i} \tan \beta_{i}}
$$

The root zone (interception store) first receives rainfall on the $\mathrm{i}^{\text {th }}$ grid cell and root zone storage $S_{r z}(i, t)$ changes over time as follows

$$
S_{r z}(i, t)=S_{r z}(i, t-1)+R(i, t)-E(i, t)
$$

Where $R$ is rainfall and $E$ is the potential evapotranspiration. If available water in the interception zone is not enough to meet evapotranspiration demand, model takes water from infiltration zone. The excess of root zone storage $\left(S_{r z}(i, t)-S_{r z m a x}(i, t)\right)$ overflows into the infiltration zone and its storage $S_{u z}(i, t)$ can be given as

$$
S_{\text {uz }}(i, t)=S_{\text {uz }}(i, t-1)+S_{\text {rz }}(i, t)-S_{\text {rzmax }}(i, t)
$$

Overland flow from grid cell $I, q_{o f}(i, t)$ can be given as follows

$$
q_{\text {of }}(i, t)=S_{u z}(i, t)-S(i, t)
$$

The decline of local transmissivity with decreasing storage in the soil profile has been approximated by an exponential function ${ }^{1)}$. Hydraulic gradient is assumed parallel to the 
ground surface. Groundwater discharges from sub-basin outlets are determined from Eq. (7).

$$
q_{b}(i, t)=T_{0} e^{-S(i, t) / m} \tan \beta
$$

The overland flow from each grid and subsurface flow calculated at sub-basin outlets are routed to Tenjinbashi gauging station. Total discharge from the cell and surface run on to the cell is routed to the down stream along the drainage network determined from $50 \mathrm{~m}$ resolution digital elevation model distributed by Geographical Survey Institute which is under the Ministry of Land, Infrastructure and Transport using Muskingum-Cunge flow routing method.

\section{(2) Parameterization}

Four model parameters namely, lateral transmissivity under saturated conditions, decay factor, maximum root zone storage, and flood plain Manning's coefficient, are assigned as functions of land use (Table 1). The Ministry of land infrastructure and transport published the land cover details of Japan in regular intervals. The data published in 1997 was used to detect the land use distribution of the study area.

Ministry of Land Infrastructure and Transport distribute digital data sets of soil of Japan at 45" longitude and 30" latitude resolution. Surface geology distribution of the study basin is depicted in Fig. 3. Because of the difficulties in finding high resolution reliable soil property databases which can correlate $T$ and $m$ of each grid, it is assumed that soil properties are largely correlated to land use. This assumption is likely to be valid for a basin that has not significant human interference on its natural environment like the Asuwa River basin.

The Manning's roughness coefficient along the main stream and tributaries are assigned as a function of slope and the best Manning's coefficient value at the most downstream location ${ }^{5}$. Thresholds for effective drainage area values were defined to differentiate the mainstream, tributaries and flood plains. Average Manning's coefficient values found for both the main river and tributaries are 0.022 and 0.030 respectively. Flood plain Manning's coefficients were assigned based on land use type of the pixel.

\section{(3) Results}

The distributed hydrological model was applied to simulate hydrological processes of the Asuwa River basin. High flows spilled the river banks before passing Tenjinbashi and observed discharges are controlled by the hydraulic structure near to the gauging station. These happenings can not be simulated by the hydrological model. Therefore the

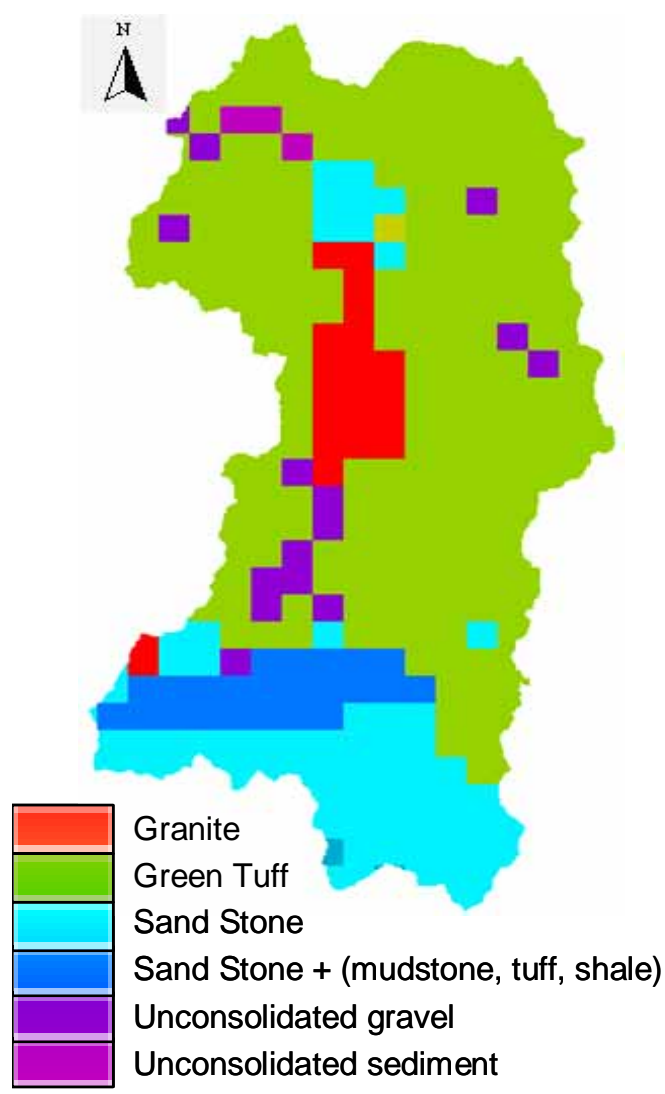

Fig. 3 Distribution of surface geology of the study area

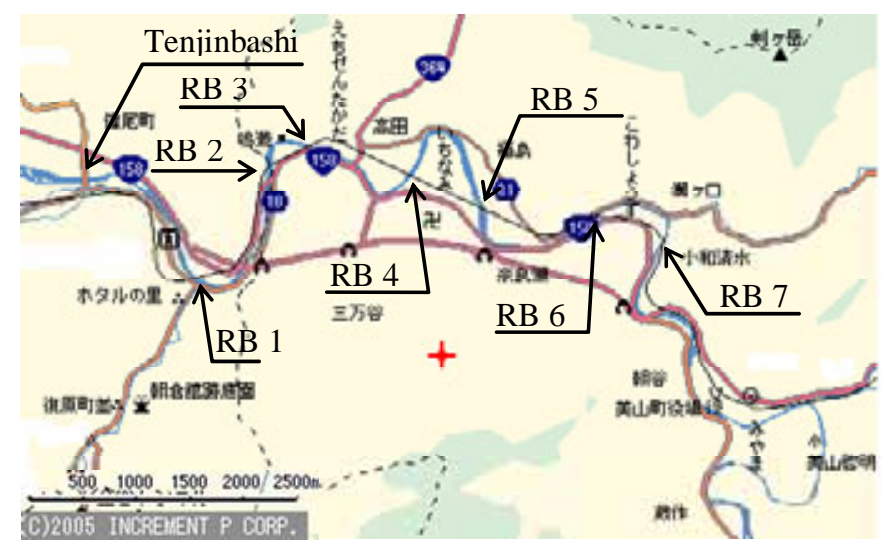

Fig. 4 Locations of the bridges subjected to sever flooding

model calibration was carried out considering higher observed peak discharge than the recorded. This assumption enhanced the upstream ungauged simulated discharges before spilling the river banks. The distributed river discharges at different points were simulated along the mainstream and tributaries of the Asuwa River basin. The simulated river discharges shown in Fig. $\mathbf{7}$ and $\mathbf{1 0}$ are used to discuss the bridge collapses in the section.

\section{ANALYSES OF COLLAPSE BRIDGES}

Ishino et al.(2005) studied collapsing mechanism of railway bridges along the Asuwa River considering constant river discharge, $2400 \mathrm{~m}^{3} / \mathrm{s}^{2}$. 
Table 2 Comparison of improved bending stresses with bearing capacities of the concrete pears of the collapses bridges

\begin{tabular}{|c|c|c|c|c|c|c|c|c|c|}
\hline RB \# & $\begin{array}{c}\text { River } \\
\text { Width } \\
(\mathrm{m})\end{array}$ & $\begin{array}{c}\text { River } \\
\text { Bed } \\
\text { Slope }\end{array}$ & $\begin{array}{c}\text { Height between } \\
\text { Deck and } \\
\text { foundation }(\mathrm{m})\end{array}$ & $\begin{array}{c}\text { Flow } \\
\text { Velocity } \\
(\mathrm{m} / \mathrm{s})\end{array}$ & $\begin{array}{c}\Sigma \mathrm{M} \\
(\text { ton.m) }\end{array}$ & $\begin{array}{c}\sigma_{\text {old }} \\
\left(\mathrm{N} / \mathrm{mm}^{2}\right)\end{array}$ & $\begin{array}{c}\sigma_{\text {ca }} \\
\left(\mathrm{N} / \mathrm{mm}^{2}\right)\end{array}$ & $\begin{array}{c}\text { Peak River } \\
\text { Flow }\left(\mathrm{m}^{3} / \mathrm{s}\right)\end{array}$ & $\begin{array}{c}\sigma_{\text {new }} \\
\left(\mathrm{N} / \mathrm{mm}^{2}\right)\end{array}$ \\
\hline 1 & 108 & $1 / 200$ & 11.5 & 2.9 & 184 & 0.17 & $0.18 \sim 2.6$ & 2650 & 0.19 \\
\hline 3 & 75 & $1 / 87$ & 11.6 & 4.8 & 484 & 0.45 & $0.18 \sim 2.6$ & 2425 & 0.45 \\
\hline 5 & 74 & $1 / 370$ & 12.3 & 3.8 & 342 & 2.86 & $0.18 \sim 2.6$ & 2368 & 2.82 \\
\hline 7 & 58 & $1 / 270$ & 12.4 & 4.6 & 645 & 4.75 & $0.31 \sim 3.3$ & 2323 & 4.60 \\
\hline
\end{tabular}

They have compared bending stresses with bearing capacities at 7 railway bridge (RB) piers. As shown in the Fig. 4, all seven analyzed JR Etsumi Hoku Line railway bridges are located within 1.5 kilometers from the Tenjinbashi gauging station of the Asuwa River.

Computed values of the bending stress and the bearing capacity of the collapsed railway bridges are shown in Table 2. The calculation was made exactly as shown in Ishino et al. ${ }^{2}$. Improvements were made in the section of calculating bending stress with computed distributed river discharges Drag force $\left(\mathrm{F}_{\mathrm{d}}\right)$ which is proportional to bending stress $(\sigma)$, is proportional to the square of flow velocity. Flow velocity (V) is proportional to river discharge (Q). Hence multiplication factor (MI) is estimated based on following scenarios.

$$
\begin{aligned}
& \sigma \propto F_{d} \propto V^{2} \propto Q^{2} \\
& \mathrm{MI}=\left(\mathrm{Q}_{\text {new }} / 2400\right)^{2} \\
& \sigma_{\text {new }}=\sigma_{\text {old }} \times \mathrm{MI}
\end{aligned}
$$

where $\sigma_{\text {new }}$ and $\sigma_{\text {old }}$ are the bending stresses calculated using simulated river discharges and $2400 \mathrm{~m}^{3} / \mathrm{s}$ respectively.

Flood situation of the collapsed railway bridge 1 is shown from Fig. 5 to Fig. 7. High river flow has submerged the railway bridge before its piers were collapsed. According to the Flood hydrograph at Tenjinbashi the maximum observed flow was 2320 $\mathrm{m}^{3} / \mathrm{s}$. However as discussed earlier, resulted high flows exceeded river levee height and over flowed to the flood plains resulting smaller observed river flows at Tenjinbashi. Also river flow controlling structures upstream of Tenjinbashi blocked the free river flow, and back-water propagation had been observed. Simulated discharge at the Tenjinbashi is $2651 \mathrm{~m}^{3} / \mathrm{s}$. According to the simulated hydrograph, the falling limb of the hydrograph has very steep slope. However observed hydrograph lags the high flows in falling limb due to returns flows of spilled water.

Fig. 8 shows the collapsed bridge at the RB 3 .

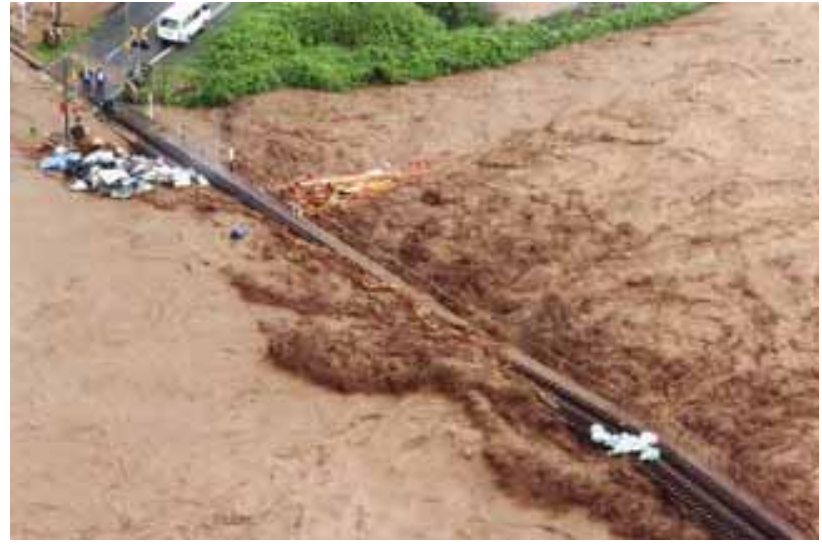

Fig. 5 Flood situation of the RB1 at 11:24 (source Fukui Newspaper)

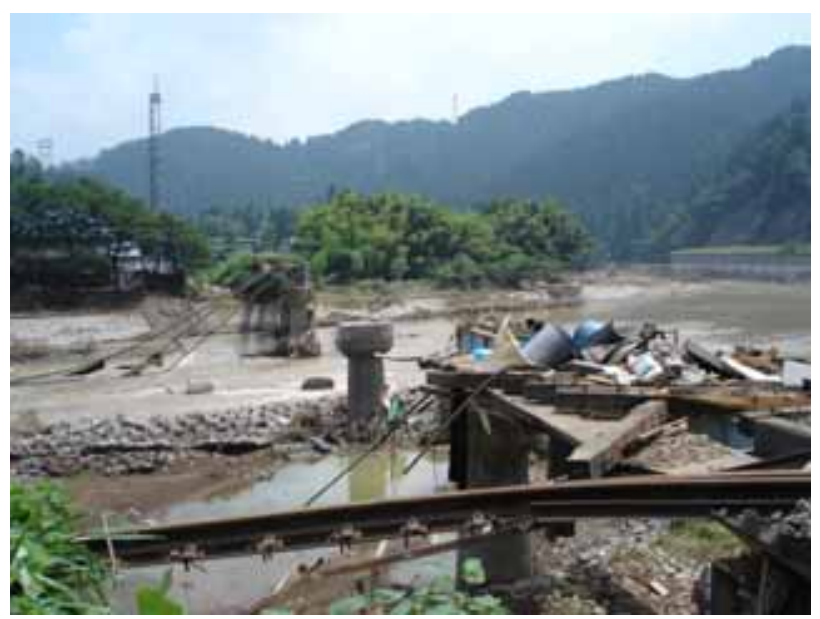

Fig. 6 Collapsed RB 1

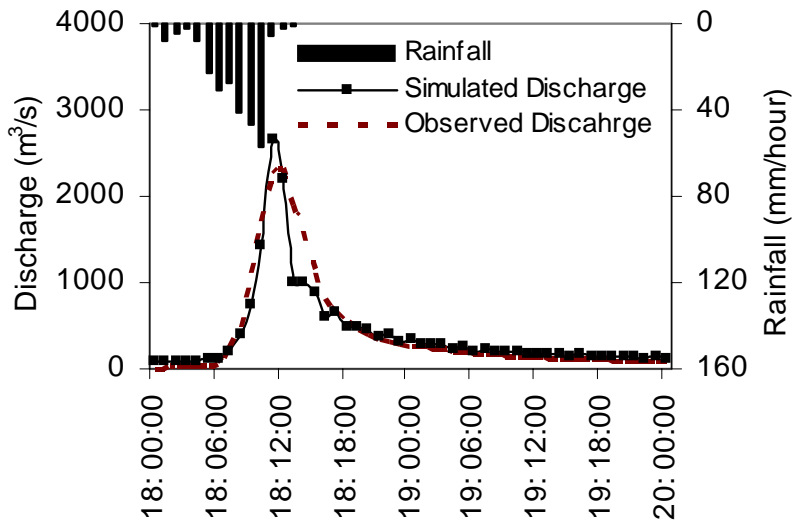

Fig. 7 Flood Hydrograph at Tenjinbashi (RB 1) 
Peak flow at RB 3 was $2425 \mathrm{~m}^{3} / \mathrm{s}$. In the case of $\mathrm{RB} 7$, where river width is $58 \mathrm{~m}$, peak discharge is $2323 \mathrm{~m}^{3} / \mathrm{s}$ inducing higher bending stress (4.75 $\mathrm{N} / \mathrm{mm}^{2}$ ) and totally washed away the railway bridge. Fig. 9 and Fig. 10 show the collapsed bridge and the flood hydrograph of the section.

\section{CONCLUSION REMARKS}

Sub-basin TOPMODEL and Muskingum Cunge flow routing with distributed parameterization using land use distribution was used to simulate hydrological processes of the Asuwa River flood disaster in July 2004.

Radar derived rainfall at 96 locations were used as input to the model. Analysis was made to study the importance of using radar derived rainfall instead of limitedly available ground measured rainfall. It was found that the basin average values estimated from different interpolating techniques and the radar derived rain have subtle differences. Nevertheless spatial distribution of rainfall which ultimately controls river discharges of medium to large-scale basins shows significant difference during the storm.

Bending stresses of the damaged railway bridge piers were compared with the bearing capacity of the construction materials at the time of collapse. The distributed hydrological model can be used to study the bridge collapsing scenarios due to high flows at any location of the basin. This methodology can be used to understand the vulnerability of river structures in ungauged river watershed.

ACKNOWLEDGMENT: The authors would like to acknowledge the River Environment Fund (Principle Researcher: Prof. N. Tamai).

\section{REFERENCES}

1) Tachikawa, Y., Takubo, R., Sayama, T. and Takara, K.:Estimation of Heavy Flood Discharge on Fukui Rainfall

Disaster 2004 and Some Recommendations on Flood Control Planning for small scale catchments, Annuals of Disas. Prev. Res. Inst., Kyoto Univ., No. 48 B, 2005, in printing.

2) Ishino, K., Umeda, S. and Tamai, N.: Study on the causes of collapsed bridges during the disaster in Fukui 2004.7 and investigation on extending life of bridges, Advances in River Engineering, JSCE, Vol.11, pp.157-162, 2005.

3) Kato, T. and Aranami, K.: Formation factors of 2004 Niigata-Fukushima and Fukui heavy rainfalls and problems in the predictions using a cloud-resolving model, SOLA, Electronic Journal of the Meteorological Society of Japan, Vol.1, pp.1-4, 2005.

4) Beven, K.J. and Kirby M.J.: A physically based variable contributing area model of hydrology. Hydrological science bulletin, Vol.24(1), pp.43-69, 1979.

5) Takeuchi, K, Tianqi, A. and Ishidaira, H.: Introduction of block-wise of TOPMODEL and Muskingum-Cunge method for hydro-environmental simulation of large

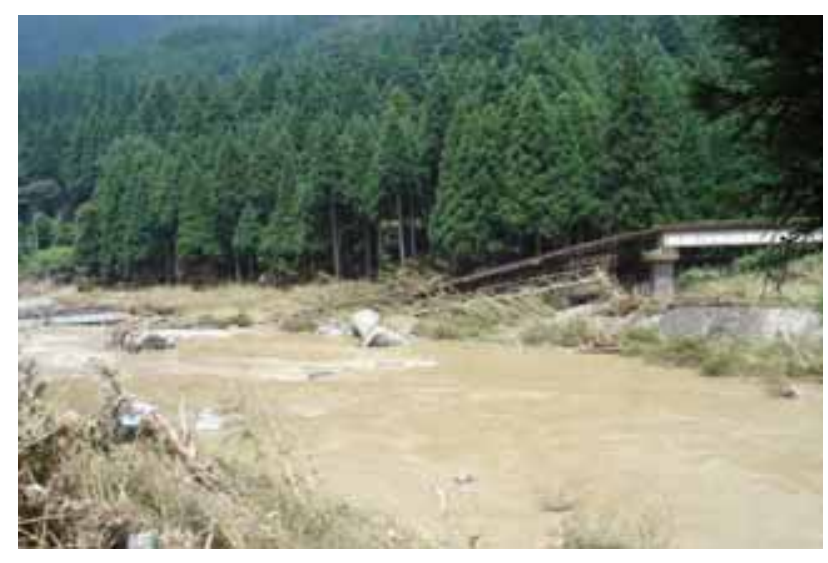

Fig. 8 Collapsed RB 3

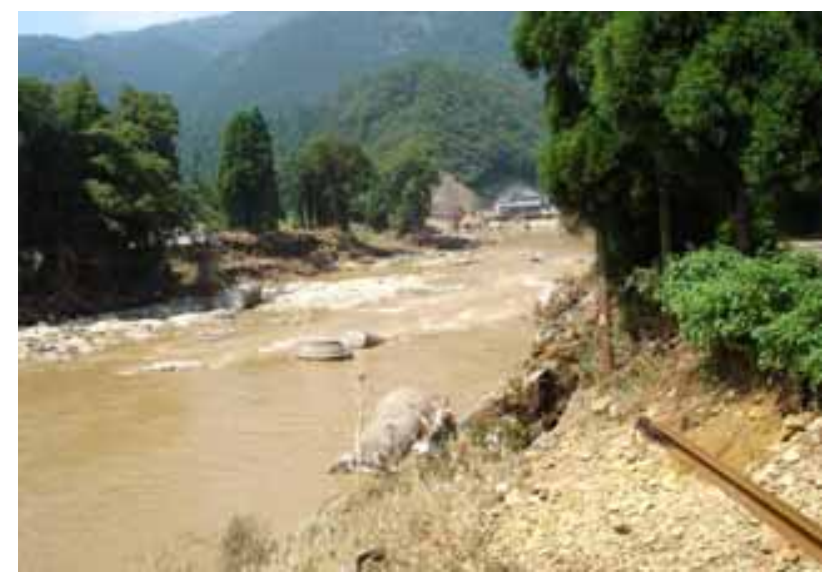

Fig. 9 Collapsed RB 7

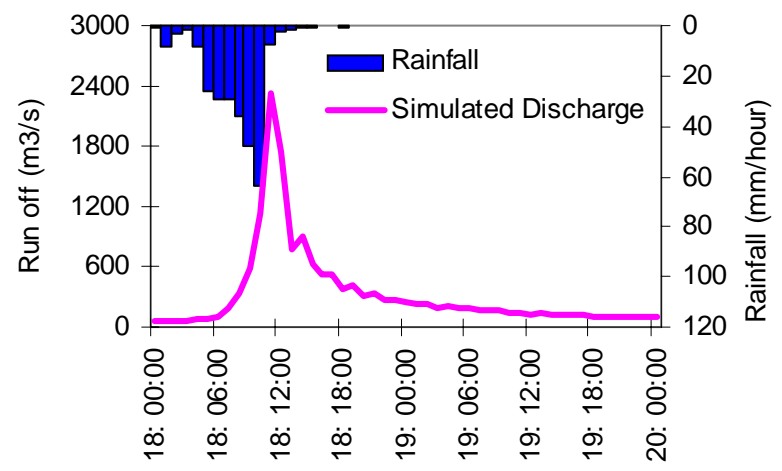

Fig. 10 Flood Hydrograph at RB 7

ungauged basins. Special Issue of Hydrological science, Vol. 44, no 4, 633-645.1999.

6) Cunge, J.A.: On the subject of a flood propagation computation method (Muskingum Method). Journal of Hydraulic Research, Vol.7, pp.205-230, 1969.

7) Nawarathna, N.M.N.S.B., Ao, T.Q., Kazama, S., Sawamoto, M. and Takeuchi, K.: Influence of human activities on the BTOPMC model runoff simulations in large-scale watersheds, XXIX IAHR congress proceedings, Theme A, pp.93-99,2001. 